\title{
Experimental infection of Balb/c nude mice with Hepatitis E virus Fen Huang ${ }^{\dagger}$, Wen Zhang ${ }^{\dagger}$, Ga Gong, Congli Yuan, Yijia Yan, Shixing Yang, Li Cui, Jianguo Zhu, Zhibiao Yang and Xiuguo Hua*
}

\begin{abstract}
Address: Shanghai Key laboratory of Veterinary Biotechnology, School of Agriculture and Biology, Shanghai JiaoTong University, 800 Dongchuan Road, Shanghai 200240, PR China

Email: Fen Huang - huangfen6789@163.com; Wen Zhang - z0216wen@sjtu.edu.cn; Ga Gong - gongga@sjtu.edu.cn; Congli Yuan - ycl@sjtu.edu.cn; Yijia Yan - y_yan@sjtu.edu.cn; Shixing Yang - yangshixing@sjtu.edu.cn; Li Cui - lcui@sjtu.edu.cn; Jianguo Zhu -Zhu_jg@sjtu.edu.cn; Zhibiao Yang - zbyang@sjtu.edu.cn; Xiuguo Hua* - hxg@sjtu.edu.cn

* Corresponding author †Equal contributors
\end{abstract}

Published: 13 June 2009

BMC Infectious Diseases 2009, 9:93 doi:10.1 186/1471-2334-9-93

This article is available from: http://www.biomedcentral.com/I47I-2334/9/93

(C) 2009 Huang et al., licensee BioMed Central Ltd.

This is an open access article distributed under the terms of the Creative Commons Attribution License (http://creativecommons.org/licenses/by/2.0), which permits unrestricted use, distribution, and reproduction in any medium, provided the original work is properly cited.
Received: 10 July 2008

Accepted: 13 June 2009

\begin{abstract}
Background: Several animal species can reportedly act as reservoirs for Hepatitis E virus (HEV), a zoonotic pathogen. HEV and antibody to the virus have been detected in a variety of animals including rodents. Pig and rat models for HEV have been established for HEV, but a nude mouse has not yet been developed.
\end{abstract}

Methods: Balb/c nude mice were inoculated with swine HEV, both orally and via intravenous injection to insure infection. Negative control and experimental contact-exposed groups of mice were also included in the study. The liver, spleen, kidney, jejunum, ileum, cecum and colon of each mouse from all three groups were collected for reverse transcription nested polymerase chain reaction ( $R T-n P C R$ ) detection, indirect immunofluorescence observation and histopathologic examination. The sera from nude mice were tested for anti-HEV IgG by enzyme linked immunosorbent assay (ELISA). Activities of liver enzymes, including alanine aminotransferase $(A L T)$, aspartate aminotransferase (AST) and alkaline phosphatase (ALP), as well as total bilirubin (TBIL) were also measured in the sera of the nude mice.

Results: HEV antigens and HEV RNA were detected in liver, spleen, kidney, jejunum, ileum and colon both by indirect immunofluorescence and by RT-nPCR in all of the inoculated and in one of the contact-exposed nude mice. Histopathological changes were observed in the liver and spleen of these mice. Infected mice showed increased levels of AST, ALP, and anti-HEV IgG in sera. The livers of contact-exposed mice showed obvious histopathological damage.

Conclusion: Nude mice could be readily infected by HEV isolated from pigs. The nude mouse may therefore be a useful animal model for studying the pathogenesis of HEV.

\section{Background}

Hepatitis E (HE) is an acute self-limiting disease in adults that has particularly high mortality in pregnant women. The causative agent of HE, the HEV, is a zoonotic pathogen that is transmitted primarily by a fecal-oral route
$[1,2]$. HEV shows cross-species transmission in pigs, chickens, rats, deer, cats and cattle [3-8]. Rodents are considered to be a potential reservoir of HEV because antiHEV antibodies are widespread in both domestic and wild rats [9-13]. 
Some unsubstantiated evidence has even suggested that domestic rats may have been the original source of human HEV infection [11]. HEV has the ability to cross species barriers, causing infections between nonhuman primates and swine [14-19]. Therefore, from a human health standpoint, it is important to identify whether cross-species transmission is possible between swine and rodents.

Hepatitis E has widely been paid attention for antibody now found globally in the human population [7,20-22]. In developing countries, it is one of the most important causes of acute clinical hepatitis in adults [7]. Although cell culture systems for propagating hepatitis $\mathrm{E}$ have been developed [23-25], the availability of laboratory animal models is still of critical importance for studying HEV pathogenicity. The establishment of a nude mouse model for HEV infection could therefore possibly circumvent these issues. It would also have the added benefit of permitting the study of the molecular mechanisms of crossspecies transmission, as well as the evaluation of vaccines. The aim of the present study was therefore to establish a HEV infection model in nude mice to aid in identifying the essential HEV transmission routes in this animal.

\section{Methods \\ Animals}

Twelve 5-week-old, 18 22 g specific-pathogen-free (SPF) male Balb/c nude mice were purchased from the National Rodent Laboratory Animal Resources, Shanghai Branch (China) and maintained in a pathogen-free animal facility. The study protocol was approved by Animal Care and Use Committee (ACUC) of Shanghai Research Center for Biomodel Organisms. We followed guidelines of the Shanghai Research Center for Biomodel Organisms during this study. All nude mice were tested for anti-HEV IgG by ELISA (KHB, Shanghai, China). Nude mice confirmed seronegative for HEV infection by ELISA were included in the study.

\section{Virus}

The swine HEV for inoculation, characterized as genotype IV [GenBank: EF570133], was isolated from swine feces from the Shanghai area, China. The HEV RNA was detected by RT-nPCR [26,27]. Positive feces were suspended in phosphate-buffered saline (PBS), pH 7.4 with $0.01 \%$ diethyl pyrocarbonate (DEPC), at a proportion of $10 \%(\mathrm{w} / \mathrm{v})$. The suspension was centrifuged at $12000 \times \mathrm{g}$ for $10 \mathrm{~min}$, followed by filtration through $0.22 \mu \mathrm{m}$ microfilters before inoculation. Virus was inoculated into each nude mouse at a minimum viral count of $1-2 \times 10^{5} / \mathrm{ml}$ of feces supernatant, as calculated by viral genomic titer determined by Real-Time quantitative PCR $[28,29]$.

\section{Experimental Design}

Twelve SPF nude mice were randomly divided into three groups, four nude mice per group. Group No. 1 was the negative control intravenously inoculated with $0.25 \mathrm{ml}$ sterilized PBS; Group No.2 was inoculated with swine $\operatorname{HEV}(0.25 \mathrm{ml}$ intravenously and also $0.25 \mathrm{ml}$ orally [29]); Group No.3 was used for experimental contact-exposure infection and consisted of three uninoculated SPF nude mice cohabiting with one inoculated nude mouse from Group No.2. Feces were collected daily post-inoculation. Each nude mouse was humanely euthanized, at either 4, 7,14 or 21 days post-inoculation following the guidelines of the Care and Use of Laboratory Animals. Blood was collected for RT-nPCR detection, ELISA tests and enzyme activity assays. Liver, spleen, kidney, jejunum, ileum, cecum, and colon were collected, and each tissue was divided into three portions for RT-nPCR detection, indirect immunofluorescence observation and histopathologic examination, respectively. Two portions were stored at $-80^{\circ} \mathrm{C}$ until use, while the third portion was fixed in $10 \%$ neutral buffered formalin for histopathologic examination immediately upon sampling.

\section{ELISA determination}

HEV IgG was determined using a commercial ELISA kit (KHB, Shanghai, China) based on recombinant HEV fusion proteins according to the manufacturer's directions. The kit used recombinant HEV fusion proteins derived from the putative structural proteins of $\mathrm{HEV}$ as primary antibody, and contained both positive and negative controls. The cutoff values for the IgG assay were determined based on 0.22 plus the mean $\mathrm{OD}_{450}$ values of sera from uninfected nude mice ( \pm standard deviation).

\section{Serum liver chemistry profile}

The activities of ALT, AST, ALP and levels of TBIL in sera were measured with an automated biochemistry analyzer (Olympus 2700, Japan).

\section{RT-PCR detection}

Total RNA was extracted from all specimens by Trizol (Invitrogen, America), according to the manufacturer's instructions. Reverse transcription was performed using an AMV Reverse Transcriptase XL for RT-PCR (Takara, Japan) according to the manufacturer's directions. HEVspecific primers have been previously described [26]; the external primers were forward primer (P1): 5'-AATTATGCC(T)CAGTAC(T)CGG(A)GTTG-3' and reverse primer (P2): 5'-CCCTTA(G)TCC(T)TGCTGA(C)GCATTCTC-3', and the internal primers were forward primer (P3): $5^{\prime}-$ GTT(A)ATGCTT(C)TGCATA(T)CATGGCT-3' and reverse primer (P4): 5'-AGCCGACGAAATCAATTCTGTC-3'. The product of RT-nPCR was expected to be 348 base pairs. The RT-PCR protocol was performed at $30^{\circ} \mathrm{C}$ for $10 \mathrm{~min}$, $42^{\circ} \mathrm{C}$ for $30 \mathrm{~min}, 99^{\circ} \mathrm{C}$ for $5 \mathrm{~min}$ and $5^{\circ} \mathrm{C}$ for $5 \mathrm{~min}$. The 
resulting cDNA was amplified by nested PCR at $94^{\circ} \mathrm{C}$ for $2 \mathrm{~min}$, followed by $94^{\circ} \mathrm{C}$ for $30 \mathrm{sec}, 42^{\circ} \mathrm{C}$ for $30 \mathrm{sec}$ and $72^{\circ} \mathrm{C}$ for $1 \mathrm{~min}$, and repeated for 29 cycles. The PCR products were detected by electrophoresis on agarose gel containing $0.5 \mu \mathrm{g} / \mathrm{ml}$ ethidium bromide.

\section{Indirect immunofluorescence observation}

Frozen tissues were cut at a thickness of $6 \mu \mathrm{m}$ for indirect immunofluorescence observation. HEV-specific ORF2 primary antibody (ABR, America, 1:500 dilution), designed to detect capsid proteins of HEV genotypes (14 ), was added to sections and incubated at $37^{\circ} \mathrm{C}$ for 30 min. After washing with PBS, FITC-labelled goat antimouse secondary antibody (Dingguo, China, 1:500 dilution) was added and incubated at $37^{\circ} \mathrm{C}$ for $30 \mathrm{~min}$. After washing with PBS, slides were observed with a Nikon TE2000 fluorescence microscope (Japan). All specimens were tested in duplicate with positive control (specimens of HEV infected rat) and negative control (specimens of uninfected nude mice).

\section{Histopathologic examination}

Tissues for histologic examination were fixed in 10\% neutral buffered formalin, routinely processed, sectioned at a thickness of $7 \mu \mathrm{m}$, and stained with hematoxylin and eosin. The tissue sections were examined and compared with negative controls.

\section{Results}

\section{Clinical evaluation}

Evidence of clinical disease, such as acute hepatitis with icteric viral hepatitis or diarrhea in humans, was not found in any of the experimental groups.

\section{Detection of HEV RNA by RT-nPCR}

HEV RNA was detected by RT-nPCR, beginning four days after inoculation in feces from all inoculated nude mice. In livers, spleens, kidneys, jejunums, ileums and colons, RNA was detected 4, 7 and 14 days post-inoculation, and in sera on days 4 and 7 post-inoculation. HEV RNA was detected in the feces of only one of the contact-exposed mice from day 7 to 20 post-inoculation, but was found in liver, spleen, kidney and sera sampled on day 14. However, HEV RNA was not detected in any of the tissues, sera or feces in the negative controls.

\section{ELISA determination}

An increased anti-HEV IgG was seen in all inoculated mice compared with the negative control group. Although IgG was also elevated in the contact-exposured group, but the increase was slower to appear and lower in magnitude than that seen in the inoculated group. All assays were performed in triplicate and data are expressed as means $( \pm$ standard deviation). The mean values of $\mathrm{OD}_{450}$ for the three groups were analyzed by SAS System software [Figure 1].

\section{Liver enzyme profile}

Liver enzyme activities were characterized using an automated biochemistry analyzer. There were no significant differences in the levels of TBIL or ALT among the three groups. The level of AST was increased (about 2.6 fold) in the inoculated group (No.2) and moderately increased in contact-exposed group (No.3) compared with the negative control group (No.1). The level of ALP was increased in both the inoculated group (No.2) and the contactexposed group (No.3) [Figure 2A]. All procedures were performed in triplicate and data are expressed as means $( \pm$

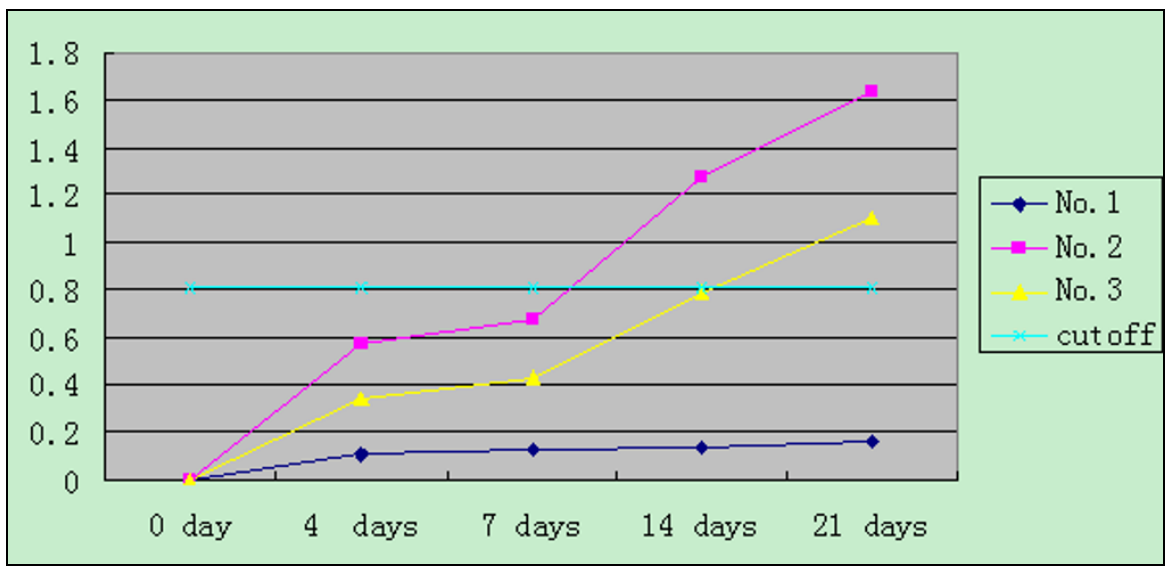

\section{Figure I}

Anti-HEV IgG in nude mice as determined by ELISA. Anti-HEV IgG was significantly elevated in the inoculated group (No.2, pink line) but increases were slower to appear in the contact-exposed group (No.3, yellow line). No changes were seen in the negative control group (No. I, dark line). The cutoff is $0.22+$ the mean values of the negative control (blue line). 


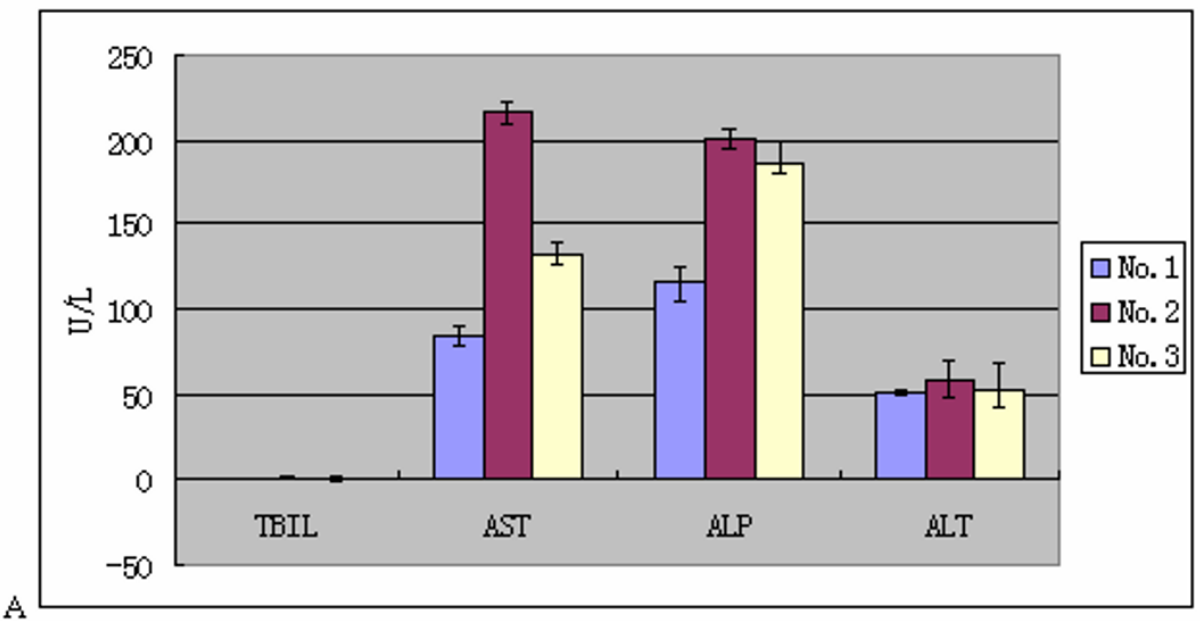

A

TBIL
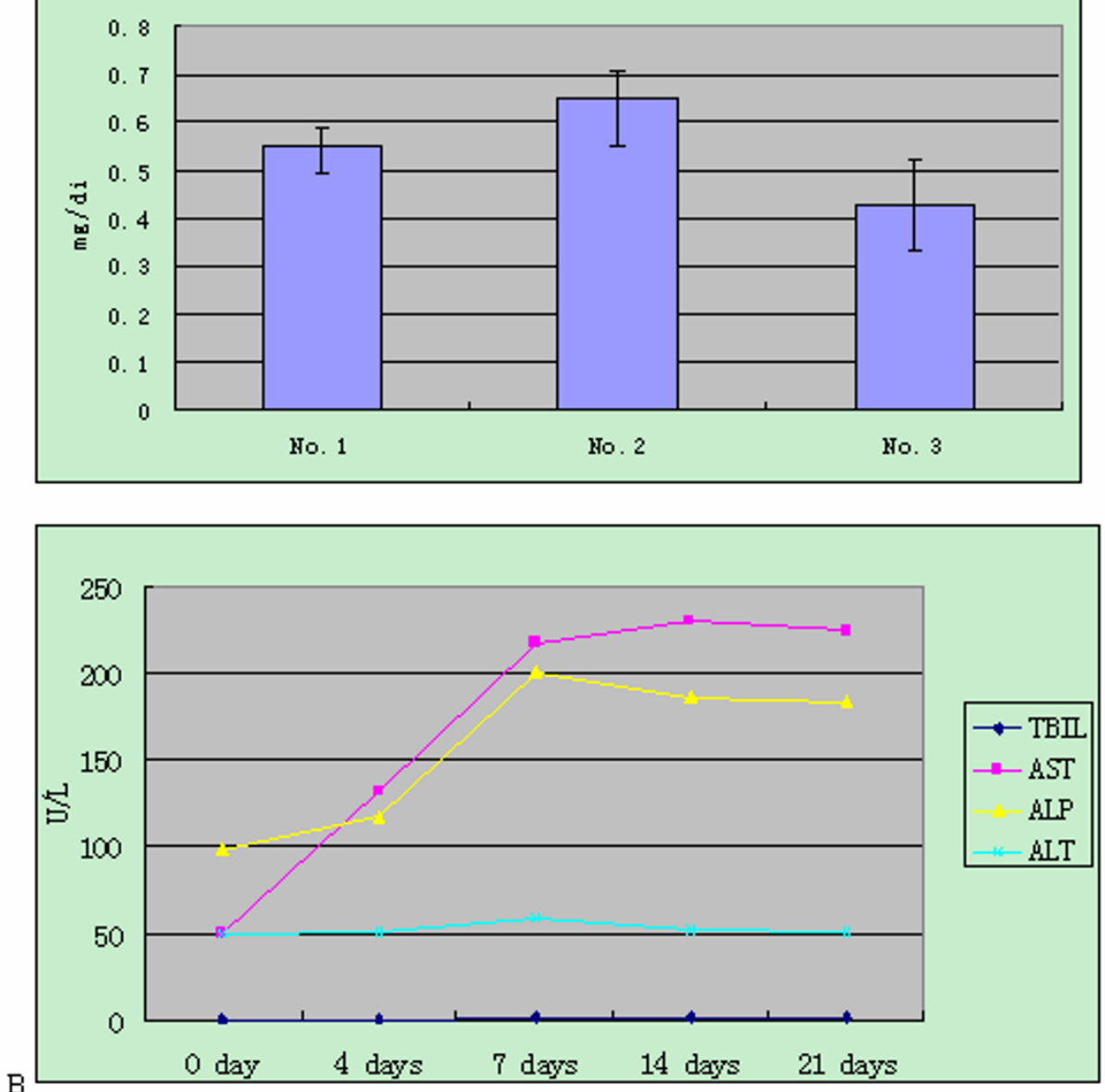

Figure 2

Changes in enzyme activities for AST, ALP, ALT and in levels of TBIL. A: The levels of AST, ALP, ALT activities and TBIL in the uninoculated group, the inoculated group and the contact-exposed group 7 days post-inoculation. The data represent the average of three experiments, with the standard deviation indicated by error bars. B: Enzyme activity changes in nude mouse in three groups. 
S.D.). The changes in the three enzyme activities and in bilirubin levels (AST, ALT, ALP, and TBIL) among three groups are shown in [Figure $2 \mathrm{~B}$ ].

\section{Indirect immunofluorescence}

HEV antigens were observed by indirect immunofluorescence in liver, spleen, kidney, jejunum, ileum and colon in the inoculated group on days 4 and 7, and in one of member of contact-exposed group on day 7 using appropriate controls [Figure $3 \mathrm{~A}-\mathrm{F}$ ]. HEV antigen was consistently detected in the cytoplasm [Figure 3A], splenocytes [Figure 3B] and renal cells [Figure 3C], and interspersed in jejunum [Figure 3D], ileum [Figure 3E] and colon [Figure $3 \mathrm{~F}]$ in all the inoculated mice and in one of the contactexposed mice. The HEV antigen was abundant in the liver and especially in the spleen. We also identified several potential HEV replication sites in jejunum, ileum and colon that have not been reported in nude mice prior to this study. As we expected, one of the contact-exposed mice showed HEV antigens in spleen, liver, and colon, which is consistent with previous studies following contact exposure transmission $[11,13,30]$. We found no signal in any of the negative control tissues [Figure $3 \mathrm{H}$ ].

\section{Histopathologic examination}

Histopathologic examination of the livers showed enlargement in one of inoculated mice, with liver capsules filled with inflammatory exudates and liver hemorrhage [Figure 4-A-1]. Hepatic inflammation, focal hepatocelluar necrosis and liver hemorrhage were observed in all inoculated mice, as well as in the contact-exposed group [Figure 4-A-2]. The hepatic lesions were mild in contact-exposed mice but severe in the inoculated ones. Lymphocytic, necrotic and cellular debris was observed in the spleens of inoculated mice and in milder form in contact-exposed mice [Figure 4-A-3]. Increased expression of infiltrating lymphocytes and macrophages in renal cells were observed [Figure 4-A-4]. No damage was observed in any
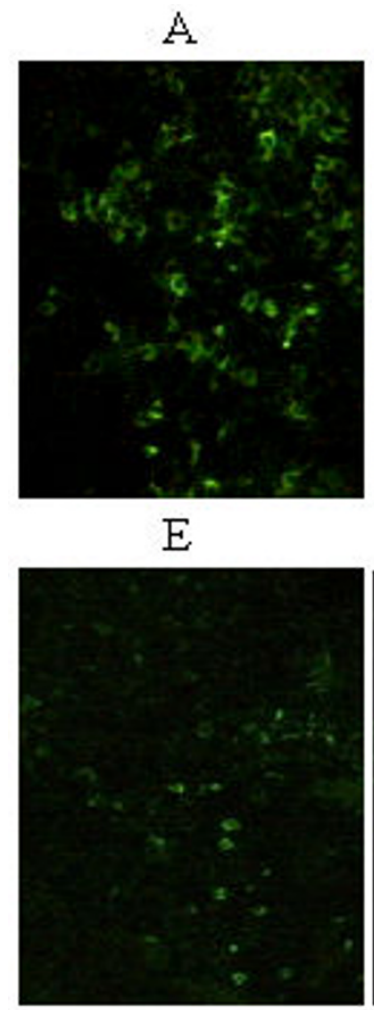

B

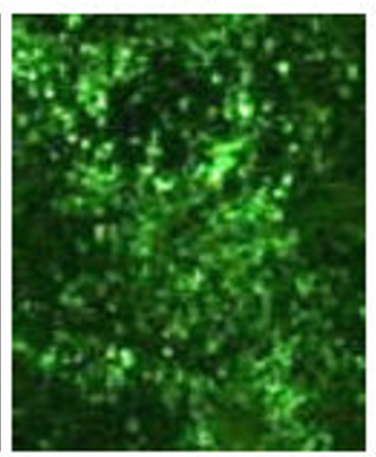

F

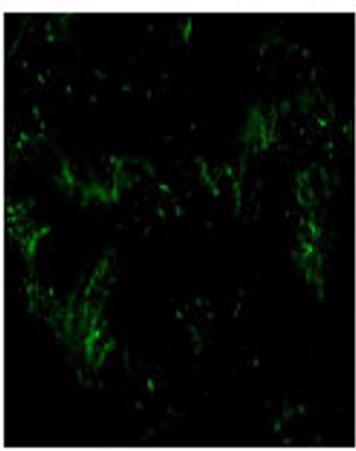

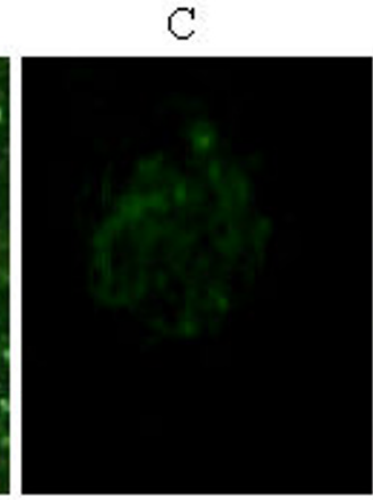

G

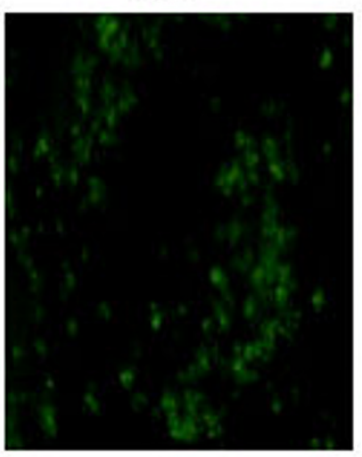

D

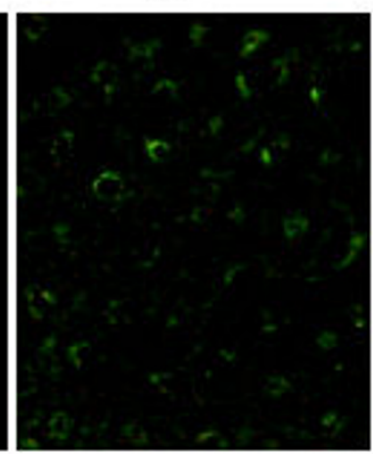

$\mathrm{H}$

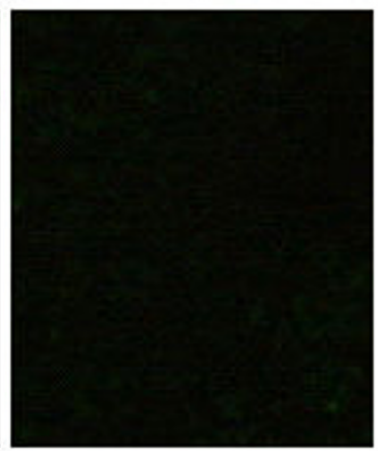

\section{Figure 3}

HEV antigen distribution in tissues of inoculated nude mice detected by indirect immunofluorescence 4d postinoculation. A: liver, granular fluorescence of HEV antigens distributed throughout hepatocytes, $\times 200$; B: spleen, distinct granular fluorescence of HEV antigens distributed throughout the cytoplasm, especially around the venous sinus, $\times$ I00; C: kidney, dozens of HEV antigens surrounding a renal cell, $\times 200$; D: jejunum, distinct granular fluorescence of HEV antigens distributed in the epithelial cells, $\times$ 200; E: ileum, granular fluorescence of HEV antigens distributed in the ileum, $\times 200 ; \mathrm{F}:$ colon, distinct granular fluorescence of HEV antigens distributed throughout colon, $\times$ 100; G: positive control, liver of HEV infected rat, $\times$ 100; $\mathrm{H}$ : negative control, liver of a nude mouse from the negative control group, $\times 200$. 
of the negative control tissues [Figure 4-B 5 to 4-B 8]. The biochemical, histologic, virologic and serologic changes caused by HEV inoculation and/or contact exposure is briefly summarized in Table 1.

\section{Discussion}

The results presented here strongly suggest that nude mice are susceptible to swine HEV as evidenced by viral antigen expression in liver and other extra-hepatic tissues, fecal viral shedding, hepatic lesions, and the presence of antiHEV antibodies. The inoculated mice showed no clinical signs of HEV infection, as has been previously reported for other animal models, such as pigs and rats $[14,10,31,11,18]$. These findings reported here are helpful for the study of the replication mechanism, transmission and pathogenesis of HEV.

We first detected HEV RNA in the feces 4 days post-inoculation in agreement with previous findings in rats (4 day) [11], cynomolgus macaques (4-6 day) [14] and pigs (7 day) [32]. In one of the contact-exposed nude mice, HEV RNA was first detected 7 days post-inoculation; i.e., 3 days later than in the directly inoculated mice. This delay reflected the lag time for virus to appear in the feces of the cohabiting inoculated mouse, and indicates that contact exposure infection occurred primarily by a fecal-oral route. In the liver, spleen, kidney, and colon of inoculated mice, HEV RNA was detected by RT-nPCR on day 4, 7, and 14, and HEV antigens were observed by indirect immunofluorescence. A large number of fluorescent of HEV antigen were observed in liver, spleen, and kidney, indicating these to be heavily infected tissues. Only a few suspected fluorescent HEV antigens were seen in the jejunum, ileum and colon [Figure 3]. This would indicate that HEV was probably replicating in these tissues, which is consistent with the previous studies [33], but this need to be further demonstrated with in situ hybridization. We detected HEV RNA in sera on day 4 and 7, but were unable to perform daily serum collection. In nonhuman primates and swine, the HEV RNA can be detected in bile [33], but it is not possible to obtain bile from a nude mouse owing to its small body size.

HEV infection in rats has been shown to have some aspects in common with HEV infection in nonhuman primates and swine; but one exception was that levels of ALT liver enzymes did not become elevated [11]. In the current study, ALT levels in nude mice were also unchanged by HEV infection in nude mice. Aggarwal et al (2001) has confirmed that ALT elevation may not a useful indicator of HEV infection in primates [20]. In contrast, the level of AST was significantly elevated in inoculated ( 2.6 fold) and contact exposed nude mice ( 1.6 fold). In addition, the sera of inoculated and contact exposed mice had elevated ALP activities, but no increases in TBIL were seen in response to $\mathrm{HEV}$ infection over the 21 days duration of the study.

The presence of HEV in stool can serve as a major source of transmission by contact exposure to other animals. In the current study, one of the contact-exposed mice became infected from viruses excreted by an inoculated

Table I: Biochemical, histologic, virologic and serologic changes in response to experimental inoculation of nude mice with HEV

\begin{tabular}{|c|c|c|c|c|}
\hline Group & & No.I & No.2 & No.3 \\
\hline \multirow[t]{8}{*}{ HEV-RNA (feces) } & Od & - & - & - \\
\hline & $4 d$ & - & $+(4 / 4)$ & - \\
\hline & $7 d$ & - & $+(4 / 4)$ & $+(I / 4)$ \\
\hline & $14 d$ & - & $+(4 / 4)$ & $+(I / 4)$ \\
\hline & $21 d$ & - & - & - \\
\hline & Liver & - & $+(4 / 4)$ & $+(I / 4)$ \\
\hline & Spleen & - & $+(4 / 4)$ & $+(1 / 4)$ \\
\hline & Kidney & - & $+(4 / 4)$ & $+(I / 4)$ \\
\hline \multirow[t]{3}{*}{ HEV-antigen } & Jejunum & - & $+(4 / 4)$ & - \\
\hline & Ileum & - & $+(4 / 4)$ & - \\
\hline & Colon & - & $+(4 / 4)$ & - \\
\hline Anti-HEV IgG & & - & $+(4 / 4)$ & $+(I / 4)$ \\
\hline $\mathrm{IHC}$ & & - & $+(4 / 4)$ & $+(1 / 4)$ \\
\hline $\mathrm{ALT}$ & & --- & -- & --- \\
\hline AST & & --- & $\uparrow$ & $\uparrow$ \\
\hline ALP & & --- & $\uparrow$ & $\uparrow$ \\
\hline TBIL & & --- & --- & --- \\
\hline Histologic change & & no change & obvious & obvious \\
\hline
\end{tabular}

-: HEV RNA negative detected by RT-PCR; +: HEV RNA positive detected by RT-PCR; IgG: the positive proportions of HEV antibodies detected by ELISA 2 I days post-inoculation; IHC: the positive proportions of HEV antigen detected by indirect immunofluorescence; ---: no significant changes; $\uparrow:$ significantly elevated compared with a negative control. 


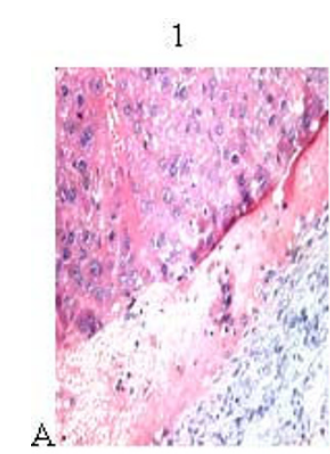

5

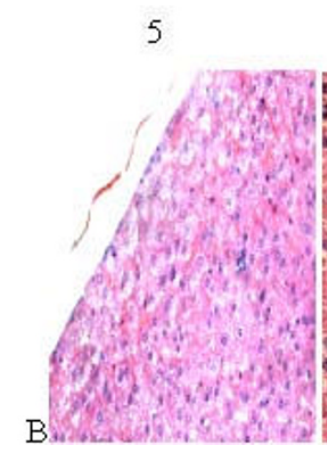

2

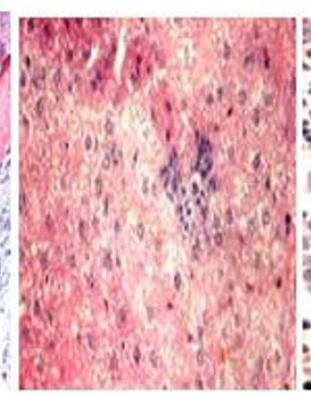

6

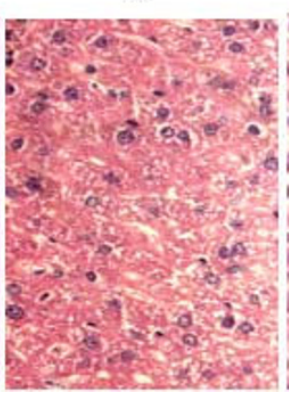

3

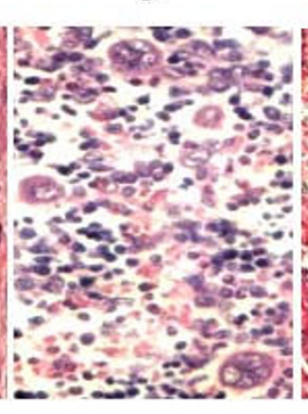

7
4

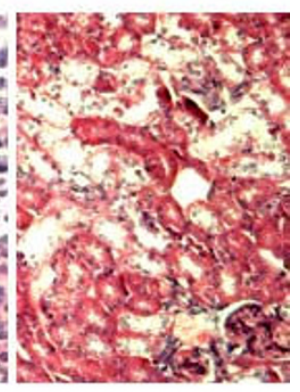

8

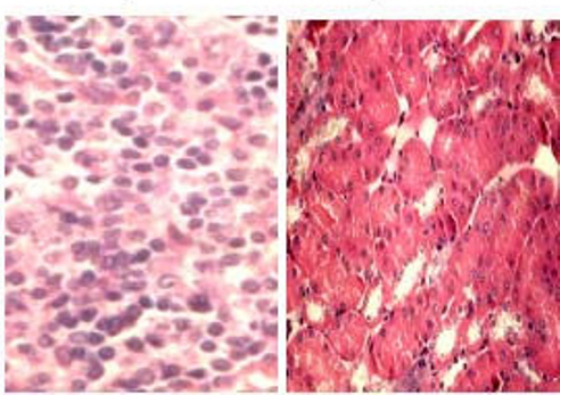

\section{Figure 4}

Histopathologic changes in the inoculated group on day 2 I. A: I, liver, one of the inoculated nude mice showed an enlarged liver filled with inflammatory exudates, $\times 200 ; 2$, liver, severe lymphoplasmacytic and histiocytic hepatitis, focal accumulation of inflammatory cells encircling hepatocytes, $\times 200 ; 3$, spleen, the ruptured and enlarged spleen displaying multiple vacuolar degeneration and focal necrosis, $\times 200 ; 4$, kidney, the disarranged kidney cells with increased lymphocytes and cellular debris, $\times 200$ B: 5, negative control liver, $\times 200 ; 6$, negative control liver, $\times 200 ; 7$, negative control spleen, $\times 200 ; 8$, negative control kidney, $\times 200$. Tissues were stained with hematoxylin and eosin.

nude mouse. This contact-exposed mouse also showed similar results to those shown by the inoculated nude mice, except that the anti-HEV antibody response was slower and AST liver enzyme levels were not as elevated. These findings are in agreement with a previous report of contact exposure in swine [13]. Taken together, the data presented here show that HEV from swine can infect nude mice and that this infection can readily occur through fecal-oral transmission.

\section{Conclusion}

HEV replication mechanisms, cross-species transmission and transmission by contact exposure could all be examined following experimental infection of Balb/c nude mice with swine HEV. Therefore the nude mouse could be considered as a promising animal model for HEV studies, especially to evaluate candidate vaccines or antiviral treatments.

\section{Competing interests}

The authors declare that they have no competing interests.

\section{Authors' contributions}

All authors participated in the planning of the project. XH was the leader of the project. FH performed the nude mice breeding and the main experiments. WZ, GG, CL, YJ carried out the IIF and ELISA determinations together with FH. SX collected all of the samples. All authors read and approved the final manuscript.

\section{Acknowledgements}

This work was supported by Key Project of Shanghai Science and Technology committee of China under Grant No.063919121.

\section{References}

I. Aggarwal R, Krawczynshi K: Hepatitis E: an overview and recent advances in clinical and laboratory research. J Gastroenterol Hepatol 2000, 15:9-20.

2. Hsieh SY, Meng XJ, Wu YH, Liu ST, Tam AW, Lin DY, Liaw YF: Identity of a novel swine hepatitis $E$ virus in Taiwan forming a monophyletic group with Taiwan isolates of human hepatitis E virus. J Clin Microbiol 1999, 37:3828-3834.

3. Feagins AR, Opriessnig T, Huang YW, Halbur PG, Meng XJ: Crossspecies infection of specific-pathogen-free pigs by a genotype 4 strain of human hepatitis E virus. J Med Virol 2008, 80:1379-1386.

4. Arankalle VA, Joshi MV, Kulkarni AM, Gandhe SS, Chobe LP, Rautmare SS, Mishra AC, Padbidri VS: Prevalence of anti-hepatitis E virus antibodies in different Indian animal species. J Viral Hepat 200I, 8:223-227. 
5. Huang FF, Sun ZF, Emerson SU, Purcell RH, Shivaprasad HL, Pierson FW, Toth TE, Meng XJ: Determination and analysis of the complete genomic sequence of avian hepatitis E virus (avian HEV) and attempts to infect rhesus monkeys with avian HEV. J Gen Virol 2004, 85:1609-1618.

6. Okamoto H, Takahashi M, Nishizawa T, Usui R, Kobayashi E: Presence of antibodies to hepatitis $E$ virus in Japanese pet cats. Infection 2004, 32:57-58.

7. Tei S, Kitajima N, Takahashi K, Mishiro S: Zoonotic transmission of hepatitis $\mathrm{E}$ virus from deer to human beings. Lancet 2003, 362:37I-373.

8. Vitral CL, Pinto MA, Lewis-Ximenez LL, Khudyakov YE, dos Santos $D R$, Gaspar AM: Serological evidence of hepatitis E virus infection in different animal species from the Southeast of Brazil. Mem Inst Oswaldo Cruz 2005, I 00: I 17-122.

9. Hirano M, Ding X, Li TC, Takeda N, Kawabata H, Koizumi N, Kadosaka T, Goto I, Masuzawa T, Nakamura M, Taira K, Kuroki T, Tanikawa $\mathrm{T}$, Watanabe $\mathrm{H}$, Abe K: Evidence for widespread infection of hepatitis E virus among wild rats in Japan. Hepatol Res 2003, 27:I-5.

10. Kabrane-Lazizi Y, Fine JB, Elm J, Glass GE, Higa H, Diwan A, Gibbs C $\mathrm{Jr}$, Meng XJ, Emerson SU, Purcell RH: Evidence for widespread infection of wild rats with hepatitis $E$ virus in the United States. Am J Trop Med Hyg 1999, 61:33 I-335.

II. Maneerat Y, Clayson ET, Myint KS, Young GD, Innis BL: Experimental infection of the laboratory rat with the hepatitis $E$ virus. J Med Virol 1996, 48: I2I-128.

12. Purcell RH, Emerson SU: Animal models of hepatitis $\mathbf{A}$ and $\mathbf{E}$. ILAR J 200I, 42: I6I-I77.

13. Bouwknegt M, Frankena K, Rutjes SA, Wellenberg GJ, de Roda Husman AM, Poel WH van der, de Jong MC: Estimation of hepatitis $\mathbf{E}$ virus transmission among pigs due to contact exposure. Vet Res 2008, 39:40.

14. Aggarwal R, Kamili S, Spelbring J, Krawczynski K: Experimental studies on subclinical hepatitis $E$ virus infection in cynomolgus macaques. J Infect Dis 200I, 184: I 380-1385.

15. Arankalle VA, Chobe LP, Chadha MS: Type-IV Indian swine HEV infects rhesus monkeys. J Viral Hepat 2006, 13:742-745.

16. McCaustland KA, Krawczynski K, Ebert JW, Balayan MS, Andjaparidze AG, Spelbring JE, Cook EH, Humphrey C, Yarbough PO, Favorov MO, Carson D, Bradley DW, Robertson BH: Hepatitis E virus infection in chimpanzees: a retrospective analysis. Arch Virol 2000, 145:1909-1918.

17. Meng XJ, Halbur PG, Shapiro MS, Govindarajan S, Bruna JD, Mushahwar IK, Purcell RH, Emerson SU: Genetic and experimental evidence of cross-species infection by the swine hepatitis $E$. J Virol 1998, 72:97|4-972।.

18. Purcall RH, Emerson SU: Hepatitis E: an emerging awareness of an old disease. J Hepatol 2008, 48:494-503.

19. Tsarev SA, Tsareva TS, Emerson SU, Yarbough PO, Legters LJ, Moskal T, Purcell RH: Infectivity titration of a prototype strain of hepatitis E virus in cynomolgus monkeys. I Med Virol 1994, 43: $135-142$.

20. Aggarwal R, McCaustland KA: Hepatitis E virus RNA detection in serum and feces specimens with the use of microspin columns. J Virol Methods 1998, 74:209-213.

21. Meng XJ: Swine hepatitis E virus: cross-species infection and risk in xenotransplantation. Curr Top Microbiol Immunol 2003 278: $185-216$.

22. Pei $Y$, Yoo D: Genetic characterization and sequence heterogeneity of a Canadian isolate of swine hepatitis E virus. J Clin Microbiol 2002, 40:402I-4029.

23. Tanaka T, Takahashi M, Kusano E, Okamoto H: Development and evaluation of an efficient cell-culture system for Hepatitis $E$ virus. J Gen Virol 2007, 88:903-9II.

24. Takahashi M, Tanaka T, Azuma M, Kusano E, Aikawa T, Shibayama T, Yazaki Y, Mizuo H, Inoue J, Okamoto H: Prolonged fecal shedding of hepatitis E virus (HEV) during sporadic acute hepatitis E: evaluation of infectivity of $\mathrm{HEV}$ in fecal specimens in a cell culture system. I Clin Microbiol 2007, 45:367I-3679.

25. Lorenzo FR, Tanaka T, Takahashi H, Ichiyama K, Hoshino Y, Yamada $\mathrm{K}$, Inoue J, Takahashi M, Okamoto $\mathrm{H}$ : Mutational events during the primary propagation and consecutive passages of hepatitis E virus strain JE03-1760F in cell culture. Virus Res 2008, 137:86-96.
26. Huang FF, Haqshenas G, Guenette DK, Halbur PG, Schommer SK, Pierson FW, Toth TE, Meng XJ: Detection by reverse transcription-PCR and genetic characterization of field isolates of swine hepatitis $E$ virus from pigs in different geographic regions of the United States. J Clin Microbiol 2002, 40:1 326-1332.

27. Kasorndorkbua C, Halbur PG, Thomas PJ, Guenette DK, Toth TE, Meng XJ: Use of a swine bioassay and a RT-PCR assay to assess the risk of transmission of swine hepatitis $E$ virus in pigs. J Virol Methods 2002, I01:71-78.

28. Li X, Kamili S, Krawczynski K: Quantitative detection of hepatitis E virus RNA and dynamics of viral replication in experimental infection. I Viral Hepat 2006, I3:835-839.

29. Kasorndorkbua C, Guenette DK, Huang FF, Thomas PJ, Meng XJ, Halbur PG: Routes of transmission of swine hepatitis $E$ virus in pigs. J Clin Microbiol 2004, 42:5047-5052.

30. Lee YH, Ha Y, Ahn KK, Chae C: Localisation of swine hepatitis $\mathbf{E}$ virus in experimentally infected pigs. Vet $J 2009$, 179:4|7-42I.

3I. Kasorndorkbua C, Thacker BJ, Halbur PG, Guenette DK, Buitenwef RM, Royer RL, Meng XJ: Experimental infection of pregnant gilts with swine hepatitis E virus. Can J Vet Res 2003, 67:303-306.

32. Halbur PG, Kasorndorkbua C, Gilbert C, Guenette D, Potters MB, Purcell RH: Comparative pathogenesis of infection of pigs with hepatitis $E$ viruses recovered from a pig and a human. Clin Microbiol 200I, 39:9I8-923.

33. Williams TPE, Kasorndorkbua C, Halbur PG, Haqshenas G, Guenette DK, Toth TE, Meng XJ: Evidence of extrahepatic site of replication of the hepatitis E virus in a swine model. J Clin Microbiol 200I, 39:3040-3046.

\section{Pre-publication history}

The pre-publication history for this paper can be accessed here:

http://www.biomedcentral.com/1471-2334/9/93/prepub

Publish with BioMed Central and every scientist can read your work free of charge

"BioMed Central will be the most significant development for disseminating the results of biomedical research in our lifetime. "

Sir Paul Nurse, Cancer Research UK

Your research papers will be:

- available free of charge to the entire biomedical community

- peer reviewed and published immediately upon acceptance

- cited in PubMed and archived on PubMed Central

- yours - you keep the copyright 